\title{
Persepsi Masyarakat Terhadap Pembuatan Gigi Tiruan oleh Tukang Gigi di Desa Treman Kecamatan Kauditan
}

\author{
${ }^{1}$ Wulan P. J. Kaunang, ${ }^{2}$ Aurelia Supit ${ }^{3}$ Ayu Angraeni \\ ${ }^{1}$ Fakultas Kedokteran Universitas Sam Ratulangi \\ ${ }^{2}$ Program Studi Kedokteran Gigi Fakultas Kedokteran Universitas Sam Ratulangi \\ ${ }^{3}$ Mahasiswa Program Studi Kedokteran Gigi Fakultas Kedokteran Universitas Sam Ratulangi
}

\begin{abstract}
ABSTRAK
Kehilangan gigi dapat menimbulkan dampak emosional serta menyebabkan berkurangnya kemampuan untuk melakukan aktivitas pengunyahan dan berbicara. Melihat akibat yang ditimbulkan maka seharusnya gigi yang hilang diganti dengan gigi tiruan. Pada umumnya untuk memenuhi kebutuhan pembuatan gigi tiruan, masyarakat lebih memilih mengunjungi tukang gigi daripada pergi ke dokter gigi. Salah satu alasan yang memengaruhi seseorang memakai gigi tiruan yaitu persepsi terhadap status kesehatan gigi. Penelitian ini merupakan penelitian deskriptif. Penelitian dilakukan di desa Treman kecamatan Kauditan berlangsung selama bulan April-Oktober 2013. Teknik pengambilan sampel dilakukan secara purposive sampling dengan membagikan kuesioner pada sampel yang berjumlah 107 orang.Hasil penelitian menunjukkan persepsi masyarakat berdasarkan waktu memiliki skor tertinggi yaitu 398 termasuk kategori baik, persepsi masyarakat berdasarkan keterjangkauan memiliki skor sebanyak 395 termasuk kategori baik, persepsi masyarakat berdasarkan biaya jumlah skor yaitu 379 termasuk kategori baik, persepsi masyarakat berdasarkan kebutuhan memiliki skor sebanyak 366,6 termasuk kategori baik, dan persepsi masyarakat berdasarkan kompetensi memiliki skor terendah yaitu sebanyak 236,25 termasuk kategori cukup.
\end{abstract}

Kata kunci : persepsi masyarakat, tukang gigi, pembuatan gigi tiruan

\begin{abstract}
Tooth loss can cause emotional effect and also reduce the ability to chew and speak. Based on these, missing teeth should be replaced with dentures. In general, to meet the needs of dentures, same people prefer visiting dental handyman rather than dentist. One of the reasons that affect a person to wear denture is the perception of dental health status. This research is a descriptive study. This study was conducted in Treman village, on april-oktober 2013. The sampling technique was done with purposive sampling by distributing questionnaires to the sample that consist of 107 people.The results of this research showed the public perception based on the time has the highest scores that is 398 including good categories, the public perception based on the affordability has 395 scores categorized as good, the public perception based on the cost has 379 scores including as good categories, the public perception based on the needs has 366,6 scores categorized as good, and the public perception based on the competence has the lowest scores as many as 236,25 including enough category.
\end{abstract}

Keywords: public perception, dental handyman, manufacture denture

Koresponden: Ayu Angraeni, Program Studi Kedokteran Gigi Fakultas Kedokteran Universitas Sam Ratulangi. E-mail: yhu_angraeni@yahoo.com

\section{PENDAHULUAN}

Gigi mempunyai peranan penting pada tubuh manusia diantaranya berfungsi untuk pengunyahan, estetik dan berbicara. Setiap individu idealnya akan mempertahankan gigi permanen alamiahnya sepanjang hidup. Namun demikian,gigi akan lepas atau perlu dicabut dengan berbagai alasan. ${ }^{1}$ Kehilangan gigi dapat disebabkan oleh beberapa hal, antara lain: trauma, karies, penyakit periodontal. ${ }^{2}$ Hal tersebut dapat menimbulkan dampak emosional bagi setiap individu misalnya rasa kurang percaya diri atau merasa malu akan penampilan dan berusaha untuk merahasiakan kehilangan giginya. Selain itu, kehilangan gigi geligi juga mengakibatkan berkurangnya kemampuan untuk melakukan aktivitas pengunyahan dan berbicara serta dapat mempengaruhi estetis. ${ }^{3}$

Data dari WHO tahun 2012 tentang kesehatan mulut menunjukkan bahwa $30 \%$ populasi di dunia pada usia 65-74 tahun telah mengalami kehilangan seluruh gigi. ${ }^{2}$ Persentase kehilangan gigi di Indonesia pada usia 35-44 tahun yaitu sebesar $0,4 \%$, semakin meningkat pada usia 65 tahun ke atas yaitu sebesar $17,6 \%$, sedangkan persentase kehilangan gigi di Sulawesi Utara yaitu $0,9 \%{ }^{4,5}$ Tidak dapat dipungkiri bahwa kehilangan gigi merupakan suatu keadaan yang sering ditemukan dimana saja, dan melihat akibat yang ditimbulkan maka sudah seharusnya gigi yang hilang tersebut diganti dengan gigi tiruan. ${ }^{6}$ 
Kebutuhan setiap orang untuk memakai gigi tiruan cukup beragam, mulai dari kebutuhan untuk menggantikan gigi yang hilang, menggantikan gigi yang telah rusak dan ada juga yang dijadikan tanda status sosial di beberapa daerah. ${ }^{7}$ Pada umumnya masyarakat untuk memenuhi kebutuhan pembuatan gigi tiruan lebih memilih mengunjungi tukang gigi daripada pergi ke tempat praktek dokter gigi yang resmi dikarenakan harga yang jauh lebih murah. ${ }^{8}$ Dalam pembuatan gigi tiruan, tukang gigi tidak memperhatikan kesehatan jaringan sekitar gigi tiruan dan pembuatannya pun hanya asal-asalan serta seringkali ditemukan adanya sisa akar yang tidak dicabut pada pemasangan gigi tiruan tersebut sehingga menimbulkan jaringan gusi yang meradang, bengkak, oral hygiene yang sangat buruk, sariawan atau denture stomatitis akibat gigi tiruan yang tidak baik adaptasinya. ${ }^{9}$

Salah satu alasan yang mempengaruhi seseorang memakai gigi tiruan yaitu persepsi terhadap status kesehatan gigi. Persepsi adalah proses kognitif yang memungkinkan seseorang dapat menafsirkan dan memahami lingkungan sekitarnya. Pada hakikatnya persepsi sebagai proses kognitif yang dialami oleh setiap orang dalam memahami informasi tentang lingkungannya, baik melalui penglihatan, pendengaran, dan penghayatan perasaan. ${ }^{10}$

Survei awal pada masyarakat di desa Treman Kecamatan Kauditan ditemukan bahwa sebagian masyarakat menggunakan gigi tiruan dengan jasa tukang gigi yang berada di desa tersebut. Berdasarkan hal-hal di atas, maka penulis tertarik untuk melakukan penelitian mengenai persepsi masyarakat terhadap pembuatan gigi tiruan oleh tukang gigi di Desa Treman Kecamatan Kauditan.

\section{BAHAN DAN METODE}

Penelitian yang dilakukan merupakan jenis penelitian deskriptif dengan menggunakan pendekatan cross sectional dan dilaksanakan didesa Treman kecamatan Kauditan. Sampel dalam penelitian ini yaitu masyarakat yang menggunakan gigi tiruan pada tukang gigi. Pengambilan sampel dilakukan dengan teknik purposive sampling, dimana sampel diambil berdasarkan pertimbangan peneliti yaitu sesuai kriteria inklusi dan eksklusi yang telah ditetapkan.
Kriteria inklusi yaitu masyarakat di desa Treman yang memakai gigi tiruan di tukang gigi berusia $\geq 25$ tahun, bersedia dengan sukarela untuk dijadikan sebagai subjek dalam penelitian ini, bersifat kooperatif selama pengambilan data. Sedangkan kriteria eksklusi yaitu masyarakat di desa Treman Kecamatan Kauditan yang memakai gigi tiruan di dokter gigi, akan dijadikan subjek penelitian tetapi berhalangan saat akan diwawancara, tidak bersifat kooperatif selama pengambilan data dan tidak bersedia sebagai subjek penelitian. Penelitian ini dilakukan dengan menggunakan data sekunder dan data primer. Pengumpulan data sekunder di peroleh dari kantor kepala desa Treman yakni berupa data profil desa, identitas, dan jumlah masyarakat. Pengumpulan data primer dilakukan dengan menggunakan kuesioner.Setelah masyarakat menandatangani informed consent, wawancara dilakukan dengan menggunakan kuesioner dan mengemukakan beberapa pertanyaan tentang persepsi masyarakat terhadap pembuatan gigi tiruan oleh tukang gigi.

Hasil dari perhitungan penilaian persepsi dalam kuesioner diukur dengan menggunakan skala likert, yaitu setiap jawaban pernyataan diberi nilai atau skor 1 hingga 5 sebagai berikut :

$\begin{array}{ll}\text { Tidak setuju } & =1 \\ \text { Kurang setuju } & =2 \\ \text { Setuju } & =3 \\ \text { Sangat setuju } & =4 \\ \text { Amat sangat setuju } & =5\end{array}$

Cara menghitung skor dalam penelitian yaitu dengan mengalikan jumlah responden yang menjawab sesuai dengan pilihan alternatif (A) jawaban dengan masing-masing nilai masingmasing alternatif jawaban (B) sebagai berikut : Jumlah skor per jawaban pertanyaan $=\mathrm{A} \times \mathrm{B}$ Jumlah skor tertinggi $=107 \times 5=535$ (ASS) Jumlah skor terendah $=107 \times 1=107$ (TS)

Data hasil pengukuran secara kontinum dapat dilihat seperti:

$\begin{array}{lcrrr} & \text { kurang } & & \text { cukup } & \text { Baik } \\ 107 & 178,3 & 356,7 & 535 & \end{array}$


Data dikumpulkan dan pengolahan data dilakukan secara manual kemudian dianalisa berdasarkan persentase dan disajikan dalam bentuk tabel dan diagram.

\section{HASIL}

Berdasarkan hasil penelitian distribusi masyarakat yang sesuai dengan jenis kelamin pada gambar 1 menunjukkan dari 107 responden di desa Treman kecamatan Kauditan terdapat 35 responden $(32,71 \%)$ berjenis kelamin laki-laki dan 72 responden $(67,29 \%)$ berjenis kelamin perempuan.

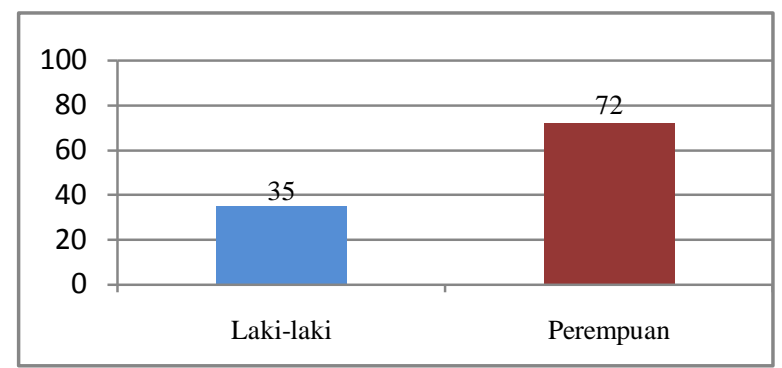

Gambar 1. Diagram distribusi responden berdasarkan jenis kelamin

Distribusi responden berdasarkan usia 25 sampai dengan usia 82 tahun pada gambar 2 jumlah responden terbanyak yaitu usia 50-82 tahun dengan jumlah 51 responden $(47,66 \%)$ dan yang paling sedikit yaitu responden yang berusia 25-30 tahun berjumlah 7 responden $(6,54 \%)$.

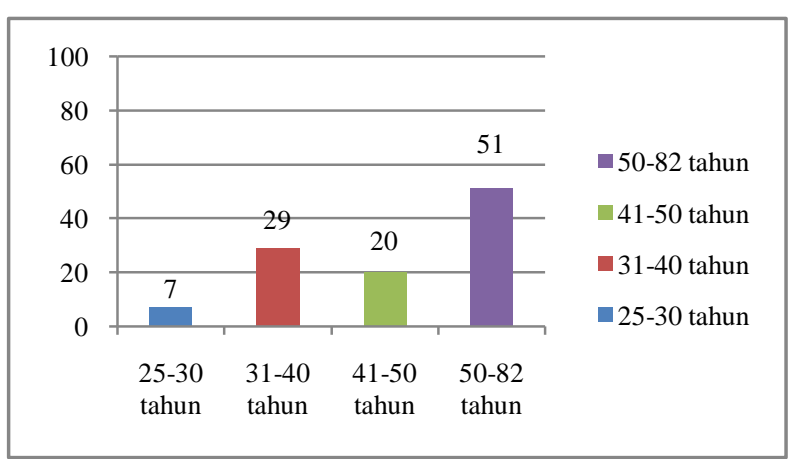

Gambar 2. Diagram distribusi responden berdasarkan rentang usia

Responden berdasarkan tingkat pendidikan pada gambar 3diketahui jumlah responden dengan tingkat pendidikan SMA merupakan responden terbanyak dengan jumlah 56 responden $(52,33 \%)$ dan yang paling sedikit yaitu responden dengan tingkat pendidikan tidak sekolah berjumlah 1 responden $(0,93 \%)$.

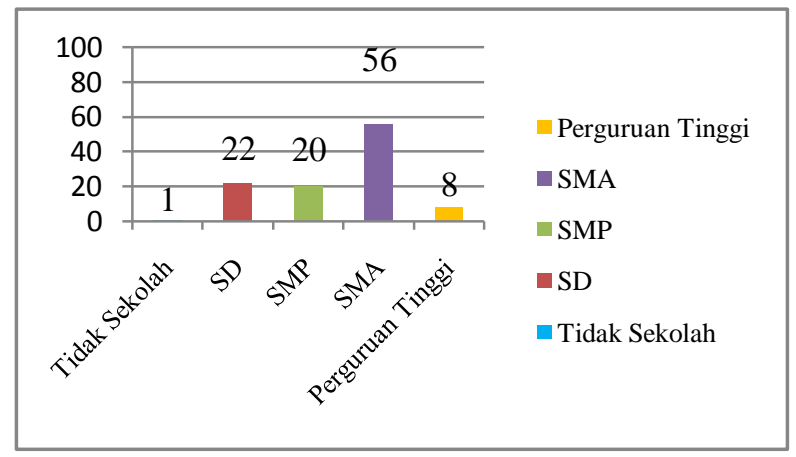

Gambar 3. Diagram distribusi responden berdasarkan tingkat pendidikan

Distribusi responden pada gambar 4 menunjukkan bahwa responden berdasarkan status pekerjaan diketahui jumlah responden dengan status pekerjaan tidak bekerja berjumlah 77(71,96\%)responden dan jumlah responden dengan status pekerjaan bekerja berjumlah 30 responden $(28,03 \%)$.

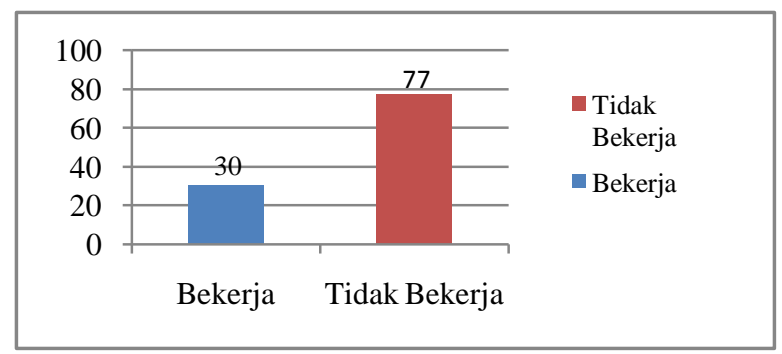

Gambar 4. Diagram distribusi responden berdasarkan status pekerjaan

Tabel 1. Distribusi frekuensi persepsi masyarakat berdasarkan kebutuhan mengenai gigi tiruan yang dibuat tukang gigi dapat menggantikan fungsi (pengunyahan, bicara, estetis) yang hilang

\begin{tabular}{lcc}
\hline \multicolumn{1}{c}{ Jawaban } & $\mathrm{N}$ & $\%$ \\
\hline Tidak setuju & 1 & 0,93 \\
Kurang setuju & 3 & 2,8 \\
Setuju & 88 & 82,24 \\
Sangat setuju & 13 & 12,15 \\
Amat sangat & 2 & 1,87 \\
setuju & & \\
\hline \multicolumn{1}{c}{ Total } & 107 & 100 \\
\hline
\end{tabular}


Pada tabel 1 dapat dilihat bahwa dari 107 responden diketahui memilih alternatif jawaban terbanyak yaitu 88 responden $(82,24 \%)$ setuju bahwa kebutuhan mengenai gigi tiruan yang dibuat tukang gigi dapat menggantikan fungsi (pengunyahan, bicara, estetis) yang hilang dan jumlah responden paling rendah yaitu 1 responden $(0,93 \%)$ tidak setuju.

Tabel 2. Distribusi frekuensi persepsi masyarakat berdasarkan kebutuhan mengenai pembuatan gigi tiruan oleh tukang gigi dapat segera menjawab kebutuhan masyarakat yang kehilangan gigi

\begin{tabular}{lcc}
\hline \multicolumn{1}{c}{ Jawaban } & $\mathrm{N}$ & $\%$ \\
\hline Tidak setuju & 0 & 0 \\
Kurang setuju & 2 & 1,87 \\
Setuju & 54 & 50,46 \\
Sangat setuju & 43 & 40,18 \\
Amat sangat & 8 & 7,47 \\
setuju & & \\
\hline \multicolumn{1}{c}{ Total } & 107 & 100 \\
\hline
\end{tabular}

Pada tabel 2 dapat dilihat bahwa dari 107 responden diketahui memilih alternatif jawaban terbanyak yaitu 54 responden $(50,46 \%)$ setuju bahwa kebutuhan mengenai pembuatan gigi tiruan oleh tukang gigi dapat segera menjawab kebutuhan masyarakat yang kehilangan gigi.
Selanjutnya sejumlah 43 responden $(40,18 \%)$ sangat setuju, 8 responden $(7,47 \%)$ amat sangat setuju, 2 responden $(1,87 \%)$ kurang setuju, dan tidak ada responden yang memilih alternatif jawaban tidak setuju.

Tabel 3. Distribusi frekuensi persepsi masyarakat berdasarkan kebutuhan mengenai pembuatan gigi tiruan oleh tukang gigi dapat cepat memulihkan rasa percaya diri yang hilang.

\begin{tabular}{lcc}
\hline \multicolumn{1}{c}{ Jawaban } & $\mathrm{N}$ & $\%$ \\
\hline Tidak setuju & 0 & 0 \\
Kurang setuju & 3 & 2,8 \\
Setuju & 50 & 46,73 \\
Sangat setuju & 37 & 34,58 \\
Amat sangat & 17 & 15,89 \\
setuju & & \\
\hline \multicolumn{1}{c}{ Total } & 107 & 100 \\
\hline
\end{tabular}

Pada tabel 3 dapat dilihat bahwa dari 107 responden diketahui memilih alternatif jawaban terbanyak yaitu 50 responden $(46,73 \%)$ setuju bahwa kebutuhan mengenai pembuatan gigi tiruan oleh tukang gigi dapat cepat memulihkan rasa percaya diri yang hilang. Selanjutnya sejumlah 37 responden $(34,58 \%)$ sangat setuju, 17 responden $(15,89 \%)$ amat sangat setuju, 3 responden $(2,8 \%)$ kurang setuju, dan tidak ada responden yang memilih alternatif jawaban tidak setuju.

Tabel 4. Distribusi frekuensi penilaian persepsi tentang kebutuhan

\begin{tabular}{|c|c|c|c|c|c|c|c|}
\hline \multirow[t]{2}{*}{ No } & $\begin{array}{c}\text { Persepsi } \\
\text { Kebutuhan }\end{array}$ & \multicolumn{5}{|c|}{ Alternatif Penilaian } & \multirow{2}{*}{ Skor } \\
\hline & & $\mathrm{TS}$ & $\mathrm{KS}$ & $S$ & SS & ASS & \\
\hline 1. & $\begin{array}{l}\text { Gigi tiruan yang dibuat tukang gigi } \\
\text { dapat menggantikan } \\
\text { (pengunyahan,bicara, estetis) } \\
\text { hilang } \\
\end{array}$ & 1 & 6 & 264 & 52 & 10 & 333 \\
\hline 2. & $\begin{array}{l}\text { Pembuatan gigi tiruan oleh tukang gigi } \\
\text { dapat segera menjawab kebutuhan } \\
\text { masyarakat yang kehilangan gigi }\end{array}$ & 0 & 4 & 162 & 172 & 40 & 378 \\
\hline \multirow[t]{3}{*}{3.} & $\begin{array}{l}\text { Pembuatan gigi tiruan oleh tukang gigi } \\
\text { dapat cepat memulihkan rasa percaya } \\
\text { diri yang hilang }\end{array}$ & 0 & 6 & 150 & 148 & 85 & 389 \\
\hline & & & & & & Total & 1100 \\
\hline & & & & & & rata Skor & 366,6 \\
\hline
\end{tabular}


Pada tabel 4. Terlihat bahwa hasil penilaian skor rata-rata pada dimensi persepsi tentang kebutuhan yaitu 366,6 dan nilai tersebut termasuk pada kategori baik, dimana alternatif jawaban yang paling banyak dipilih responden yaitu alternatif jawaban setuju sampai amat sangat setuju.

Hasil penilaian yang diperoleh secara kontinum dapat dilihat pada skala dibawah ini:

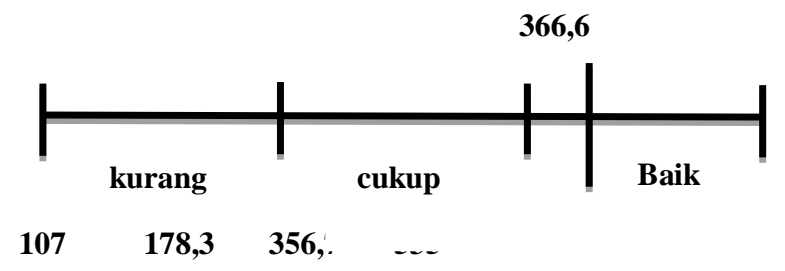

Tabel 5. Distribusi frekuensi persepsi masyarakat berdasarkan kompetensi mengenai tukang gigi mampu membuat gigi tiruan.

\begin{tabular}{lcc}
\hline \multicolumn{1}{c}{ Jawaban } & $\mathrm{N}$ & $\%$ \\
\hline Tidak setuju & 0 & 0 \\
Kurang setuju & 3 & 2,8 \\
Setuju & 80 & 74,76 \\
Sangat setuju & 24 & 22,43 \\
Amat sangat & 0 & 0 \\
setuju & & \multicolumn{1}{c}{ Total } \\
\hline
\end{tabular}

Pada tabel 5 dapat dilihat bahwa dari 107 responden diketahui memilih alternatif jawaban terbanyak yaitu 80 responden $(74,76 \%)$ setuju bahwa kompetensi mengenai tukang gigi mampu membuat gigi tiruan. Selanjutnya sejumlah 24 responden $(22,43 \%)$ sangat setuju, 3 responden $(2,8 \%)$ kurang setuju, tidak ada responden yang memilih alternatif jawaban tidak setuju dan amat sangat setuju.

Tabel 6. Distribusi frekuensi persepsi masyarakat berdasarkan kompetensi mengenai tukang gigi mampu melakukan perawatan sebelum dan setelah pemasangan gigi tiruan.

\begin{tabular}{lcc}
\hline \multicolumn{1}{c}{ Jawaban } & N & $\%$ \\
\hline Tidak setuju & 43 & 40,18 \\
Kurang setuju & 34 & 31,77 \\
Setuju & 22 & 20,56 \\
Sangat setuju & 8 & 7,47 \\
Amat sangat setuju & 0 & 0 \\
\hline \multicolumn{1}{c}{ Total } & 107 & 100 \\
\hline
\end{tabular}

Pada tabel 6 dapat dilihat bahwa dari 107 responden diketahui memilih alternatif jawaban terbanyak yaitu 43 responden $(40,18 \%)$ tidak setuju bahwa kompetensi mengenai tukang gigi mampu melakukan perawatan sebelum dan setelah pemasangan gigi tiruan. Selanjutnya sejumlah 34 responden $(31,77 \%)$ kurang setuju, 22 responden $(20,56 \%)$ setuju, 8 responden $(7,47 \%)$ sangat setuju, dan tidak ada responden yang memilih alternatif jawaban amat sangat setuju.

Tabel 7. Distribusi frekuensi persepsi masyarakat berdasarkan kompetensi mengenai dokter gigi hanya bertugas melayani masyarakat yang sakit gigi.

\begin{tabular}{lcc}
\hline \multicolumn{1}{c}{ Jawaban } & N & $\%$ \\
\hline Tidak setuju & 52 & 48,6 \\
Kurang setuju & 24 & 22,43 \\
Setuju & 26 & 24,3 \\
Sangat setuju & 5 & 4,67 \\
Amat sangat & 0 & 0 \\
setuju & & \\
\hline \multicolumn{1}{c}{ Total } & 107 & 100 \\
\hline
\end{tabular}

Pada tabel 7 dapat dilihat bahwa dari 107 responden diketahui memilih alternatif jawaban terbanyak yaitu 52 responden $(48,6 \%)$ tidak setuju bahwa kompetensi mengenai dokter gigi hanya bertugas melayani masyarakat yang sakit gigi. Selanjutnya sejumlah 24 responden $(22,43 \%)$ kurang setuju, 26 responden $(24,3 \%)$ setuju, 5 responden $(4,67 \%)$ sangat setuju, dan tidak ada responden yang memilih alternatif jawaban amat sangat setuju.

Tabel 8. Distribusi frekuensi persepsi masyarakat berdasarkan kompetensi mengenai dokter gigi tidak melayani pembuatan gigi tiruan.

\begin{tabular}{lcc}
\hline \multicolumn{1}{c}{ Jawaban } & $\mathrm{N}$ & $\%$ \\
\hline Tidak setuju & 55 & 51,42 \\
Kurang setuju & 21 & 19,62 \\
Setuju & 25 & 23,36 \\
Sangat setuju & 6 & 5,6 \\
Amat sangat setuju & 0 & 0 \\
\hline \multicolumn{1}{c}{ Total } & 107 & 100 \\
\hline
\end{tabular}

Pada tabel 8 dapat dilihat bahwa dari 107 responden diketahui memilih alternatif jawaban terbanyak yaitu 55 responden $(51,42 \%)$ tidak setuju bahwa kompetensi mengenai dokter gigi tidak melayani pembuatan gigi tiruan. Selanjutnya sejumlah 25 responden $(23,36 \%)$ setuju, 21 responden $(19,62 \%)$ kurang setuju, 6 responden $(5,67 \%)$ sangat setuju, dan tidak ada responden yang memilih alternatif jawaban amat sangat setuju. 
Tabel 9. Distribusi frekuensi penilaian persepsi tentang Kompetensi

\begin{tabular}{|c|c|c|c|c|c|c|c|}
\hline \multirow{2}{*}{ No } & \multirow{2}{*}{$\begin{array}{c}\text { Persepsi } \\
\text { Kompetensi }\end{array}$} & \multicolumn{5}{|c|}{ Alternatif Penilaian } & \multirow{2}{*}{ Skor } \\
\hline & & $\mathrm{TS}$ & KS & $S$ & SS & ASS & \\
\hline & $\begin{array}{l}\text { Tukang gigi mampu membuat gigi } \\
\text { tiruan }\end{array}$ & 0 & 6 & 240 & 96 & 0 & 342 \\
\hline & $\begin{array}{l}\text { Tukang gigi mampu } \begin{array}{r}\text { melakukan } \\
\text { perawatan sebelum dan } \\
\text { pemasangan gigi tiruan }\end{array} \\
\end{array}$ & 43 & 68 & 66 & 32 & 0 & 209 \\
\hline 3. & $\begin{array}{l}\text { Dokter gigi hanya bertugas melayani } \\
\text { masyarakat yang sakit gigi }\end{array}$ & 52 & 48 & 78 & 20 & 0 & 198 \\
\hline 4. & $\begin{array}{l}\text { Dokter gigi tidak melayani pembuatan } \\
\text { gigi tiruan }\end{array}$ & 55 & 42 & 75 & 24 & 0 & 196 \\
\hline & & & & & & Total & 945 \\
\hline & & & & & & a skor & 236,25 \\
\hline
\end{tabular}

Pada tabel 9. Terlihat bahwa hasil penilaian skor rata-rata pada dimensi persepsi tentang kompetensi yaitu 236,25 dan nilai tersebut termasuk pada kategori cukup, dimana alternatif jawaban yang paling banyak dipilih responden yaitu alternatif jawaban tidak setuju sampai sangat setuju.Hasil penilaian yang diperoleh secara kontinum dapat dilihat pada skala dibawah ini:

236,25

107

\section{Kurang}

178,3

Cukup

356,7

Baik

Tabel 10. Distribusi frekuensi persepsi masyarakat berdasarkan biaya mengenai pembuatan gigi tiruan oleh tukang gigi lebih murah dibandingkan dokter gigi.

\begin{tabular}{lcc}
\hline \multicolumn{1}{c}{ Jawaban } & N & $\%$ \\
\hline Tidak setuju & 3 & 2,8 \\
Kurang setuju & 1 & 0,93 \\
Setuju & 48 & 44,86 \\
Sangat setuju & 45 & 42,05 \\
Amat sangat setuju & 10 & 9,34 \\
\hline \multicolumn{1}{c}{ Total } & 107 & 100 \\
\hline
\end{tabular}

Pada tabel 10 dapat dilihat bahwa dari 107 responden diketahui memilih alternatif jawaban terbanyak yaitu 48 responden $(44,86 \%)$ setuju bahwa biaya pembuatan gigi tiruan oleh tukang gigi lebih murah dibandingkan dokter gigi. Selanjutnya sejumlah 45 responden $(42,05 \%)$ sangat setuju, 10 responden $(9,34 \%)$ amat sangat setuju, 3 responden $(2,8 \%)$ tidak setuju, dan jumlah responden paling rendah yaitu 1 responden $(0,93)$ yang memilih alternatif jawaban kurang setuju.

Tabel 11. Distribusi frekuensi penilaian persepsi tentang biaya

\begin{tabular}{|c|c|c|c|c|c|c|}
\hline \multirow{2}{*}{$\begin{array}{c}\text { Persepsi } \\
\text { Biaya }\end{array}$} & \multicolumn{6}{|c|}{ Alternatif penilaian } \\
\hline & $\mathscr{H}$ & $\approx$ & n & $\tilde{n}$ & $\begin{array}{l}\sqrt{2} \\
\hat{\alpha}\end{array}$ & $\frac{\bar{a}}{\Delta}$ \\
\hline $\begin{array}{l}\text { Pembuatan } \\
\text { gigi tiruan } \\
\text { oleh tukang } \\
\text { gigi lebih } \\
\text { murah } \\
\text { dibandingkan } \\
\text { dokter gigi }\end{array}$ & 3 & 2 & 144 & 180 & 50 & 379 \\
\hline & & & & Rerata & $\begin{array}{l}\text { otal } \\
\text { kkor }\end{array}$ & $\begin{array}{l}379 \\
379\end{array}$ \\
\hline
\end{tabular}

Pada tabel 11. Terlihat bahwa hasil penilaian skor rata-rata pada dimensi persepsi tentang biaya yaitu 379 dan nilai tersebut termasuk pada kategori baik, dimana alternatif jawaban yang paling banyak dipilih responden yaitu alternatif jawaban setuju sampai amat sangat setuju.

Hasil penilaian yang diperoleh secara kontinum dapat dilihat pada skala dibawah ini:

379
Cukup 356,7
Baik 
Tabel 12. Distribusi frekuensi persepsi masyarakat berdasarkan waktu mengenai pembuatan gigi tiruan oleh tukang gigi lebih cepat dari segi waktu.

\begin{tabular}{lcc}
\hline \multicolumn{1}{c}{ Jawaban } & $\mathrm{N}$ & $\%$ \\
\hline Tidak setuju & 0 & 0 \\
Kurang setuju & 1 & 0,93 \\
Setuju & 38 & 35,51 \\
Sangat setuju & 58 & 54,20 \\
Amat sangat setuju & 10 & 9,34 \\
\hline \multicolumn{1}{c}{ Total } & 107 & 100 \\
\hline
\end{tabular}

Pada tabel 12 dapat dilihat bahwa dari 107 responden diketahui memilih alternatif jawaban terbanyak yaitu 58 responden $(54,20 \%)$ sangat setuju bahwa waktu pembuatan gigi tiruan oleh tukang gigi lebih cepat dari segi waktu. Selanjutnya sejumlah 38 responden $(35,51 \%)$ setuju, 10 responden $(9,34 \%)$ amat sangat setuju, 1 responden $(0,93 \%)$ kurang setuju, dan tidak ada responden yang memilih alternatif jawaban tidak setuju.

Tabel 13. Distribusi frekuensi penilaian persepsi tentang waktu

\begin{tabular}{|c|c|c|c|c|c|c|}
\hline \multirow{2}{*}{$\begin{array}{c}\text { Persepsi } \\
\text { Waktu }\end{array}$} & \multicolumn{6}{|c|}{ Alternatif penilaian } \\
\hline & $\tilde{H}$ & $\approx$ & $\sim$ & $\approx$ & 饮 & $\begin{array}{l}\tilde{a} \\
\frac{y}{\sigma}\end{array}$ \\
\hline $\begin{array}{l}\text { Pembuatan } \\
\text { gigi tiruan } \\
\text { oleh tukang } \\
\text { gigi lebih } \\
\text { cepat dari } \\
\text { segi waktu }\end{array}$ & 0 & 2 & 144 & 232 & 50 & 398 \\
\hline & & & & & otal & 398 \\
\hline
\end{tabular}

Pada tabel 13. Terlihat bahwa hasil penilaian skor rata-rata pada dimensi persepsi tentang biaya yaitu 398 dan nilai tersebut termasuk pada kategori baik, dimana alternatif jawaban yang paling banyak dipilih responden yaitu alternatif jawaban setuju sampai amat sangat setuju.

Hasil penilaian yang diperoleh secara kontinum dapat dilihat pada skala dibawah ini:
Tabel 14. Distribusi frekuensi persepsi masyarakat berdasarkan akses mengenai praktek tukang gigi lebih mudah dijangkau.

\begin{tabular}{lcc}
\hline \multicolumn{1}{c}{ Jawaban } & $\mathrm{N}$ & $\%$ \\
\hline Tidak setuju & 0 & 0 \\
Kurang setuju & 1 & 0,93 \\
Setuju & 44 & 41,12 \\
Sangat setuju & 49 & 45,8 \\
Amat sangat setuju & 13 & 12,14 \\
\hline \multicolumn{1}{c}{ Total } & 107 & 100 \\
\hline
\end{tabular}

Pada tabel 14 dapat dilihat bahwa dari 107 responden diketahui memilih alternatif jawaban terbanyak yaitu 49 responden $(45,8 \%)$ sangat setuju bahwa akses mengenai praktek tukang gigi lebih mudah dijangkau. Selanjutnya sejumlah 44 responden $(41,12 \%)$ setuju, 13 responden $(12,14 \%)$ amat sangat setuju, 1 responden $(0,93 \%)$ kurang setuju, dan tidak ada responden yang memilih alternatif jawaban tidak setuju.

Tabel 15. Distribusi frekuensi penilaian persepsi tentang akses

\begin{tabular}{|c|c|c|c|c|c|c|}
\hline \multirow{2}{*}{$\begin{array}{c}\text { Persepsi } \\
\text { Akses }\end{array}$} & \multicolumn{6}{|c|}{ Alternatif penilaian } \\
\hline & $\mathscr{H}$ & $\tilde{z}$ & $n$ & $n$ & $\frac{n}{2}$ & $\frac{\vec{\Delta}}{\Delta}$ \\
\hline $\begin{array}{l}\text { Praktek } \\
\text { tukang gigi } \\
\text { lebih mudah } \\
\text { dijangkau }\end{array}$ & 0 & 2 & 132 & 196 & 65 & 395 \\
\hline & & & & & otal & 395 \\
\hline & & & & Rerata & skor & 395 \\
\hline
\end{tabular}

Penilaian skor rata-rata pada dimensi persepsi tentang akses yaitu 395 dan nilai tersebut termasuk pada kategori baik, dimana alternatif jawaban yang paling banyak dipilih responden yaitu alternatif jawaban setuju sampai amat sangat setuju.

Hasil penilaian yang diperoleh secara kontinum dapat dilihat pada skala dibawah ini:

395
107

Kurang
178,3

Cukup

356,7
Baik 


\section{PEMBAHASAN}

\section{Kebutuhan}

Berdasarkan hasil penelitian yang dilakukan pada masyarakat di desa Treman kecamatan Kauditan tentang persepsi responden terhadap kebutuhan, didapatkan penilaian skor rata-rata sebesar 366,6. Penilaian tersebut termasuk dalam kategori baik, dimana alternatif jawaban setuju sampai amat sangat setuju.

Seseorang yang mengalami kehilangan gigi hanya dibagian anterior membutuhkan penggantian gigi dikarenakan faktor estetika dan mereka yang kehilangan gigi hanya di bagian posterior membutuhkan penggantian gigi karena faktor pengunyahan. Osterberg dkk melaporkan bahwa faktor estetika lebih dipilih dalam menentukan kebutuhan individu daripada faktor fungsional terhadap kehilangan gigi. ${ }^{11}$

Kehilangan gigi juga dapat menimbulkan dampak emosional dan menyebabkan terjadinya stress. Penelitian yang dilakukan oleh Davis dkk di London menunjukkan bahwa dari $45 \%$ orang yang mengalami kehilangan gigi sulit menerima keadaannya dan merasa kurang percaya diri sehingga tidak ingin dilihat orang lain saat tidak memakai gigi tiruan maka dengan adanya gigi tiruan untuk menggantikan gigi yang hilang dapat mengembalikan rasa percaya diri yang hilang sehingga gangguan akan kehilangan gigi dapat di atasi. ${ }^{12,13}$

Penelitian ini menunjukkan bahwa persepsi tentang kebutuhan akan gigi tiruan sebagian besar responden telah memahami sehingga memiliki persepsi baik tentang gigi tiruan yang dibuat tukang gigi dapat menggantikan fungsi gigi (pengunyahan, bicara, estjetis) yang hilang, gigi tiruan oleh tukang gigi dapat segera menjawab kebutuhan masyarakat yang kehilangan gigi, pembuatan gigi tiruan oleh tukang gigi dapat cepat memulihkan rasa percaya diri yang hilang. Alasan responden lebih memilih tukang gigi sebagai jasa pembuatan gigi tiruan mungkin dikarenakan biaya yang relatif murah, pembuatan gigi tiruan yang lebih cepat dari segi waktu, dan keterjangkauan tempat tukang gigi.

\section{Kompetensi}

Penelitian yang dilakukan pada masyarakat di desa Treman kecamatan Kauditan tentang persepsi responden terhadap kompetensi, didapatkan penilaian skor rata-rata sebesar 236,25. Penilaian tersebut termasuk dalam kategori cukup, dimana alternatif jawaban tidak setuju sampai sangat setuju.

Tukang gigi melaksanakan pekerjaannya tanpa izin, mungkin inilah yang mendorong tukang gigi untuk melakukan suatu perawatan yang hanya berlandaskan dengan pengetahuan terbatas dan memiliki pemikiran bahwa yang terpenting yaitu kepuasan dari masyarakat yang meminta jasa tukang gigi tersebut tanpa memikirkan dampak yang akan terjadi yang akan dialami oleh pengguna jasanya.

Berdasarkan peraturan menteri kesehatan nomor 339/MENKES/PER/V/1989 tentang kewenangan tukang gigi sudah tertulis jelas bahwa tukang gigi memang mampu membuat gigi tiruan tetapi pembuatan dan pemasangan gigi tiruan yang dilakukan oleh tenaga yang tidak memiliki pengetahuan ilmiah mengenai kesehatan rongga mulut dapat menyebabkan infeksi, pembengkakan bagian wajah, hampir seluruh gusi merah dan bengkak. ${ }^{9}$ Salah satu hal penting yang tidak dijangkau oleh pemikiran tukang gigi yaitu pemberian instruksi bagi pengguna gigi tiruan. Hal ini bertentangan dengan ketentuan bahwa harus ada pemberian instruksi setelah insersi gigi tiruan.

Tukang gigi jelas berbeda kompetensinya dengan dokter gigi. Menurut Peraturan menteri kesehatan nomor 512/Menkes/Per/IV/2007 tentang izin praktek dan pelaksanaan praktek kedokteran pada bab 1 pasal 1 poin 7 menyebutkan pelayanan medis adalah pelayanan kesehatan yang diberikan oleh dokter dan dokter gigimsesuai dengan kompetensi dan kewenangannya yang dapat berupa pelayanan promotif, preventif, diagnostik, konsultatif, kuratif, atau rehabilitatif. ${ }^{14}$ Pada dokter gigi pelayanan kesehatan tidak hanya melayani masyarakat yang sakit gigi tetapi masih banyak perawatan yang bisa diberikan oleh dokter gigi salah satunya yaitu pembuatan gigi tiruan.

Hasil penelitian ini menunjukkan bahwa persepsi tentang kompetensi tukang gigi dan dokter gigi sebagian responden memiliki persepsi cukup mengenai tukang gigi mampu membuat gigi tiruan, tukang gigi mampu melakukan perawatan sebelum dan setelah pemasangan gigi tiruan, dokter gigi hanya bertugas melayani masyarakat yang sakit gigi, dan dokter gigi tidak melayani pembuatan gigi tiruan.

Penulis berasumsi bahwa responden tersebut masih ada yang belum paham akan bedanya kompetensi tukang gigi dan dokter gigi. Responden beranggapan bahwa pembuatan gigi tiruan oleh tukang gigi sama dengan pembuatan gigi tiruan yang dibuat oleh dokter gigi. Alasan lain responden lebih memilih tukang gigi daripada dokter gigi disebabkan karena di desa Treman tersebut jauh dari fasilitas kesehatan gigi dan mulut sehingga lebih memilih melakukan pembuatan gigi tiruan pada tukang gigi karena 
tukang gigi sendiri mempunyai keterampilan dalam membuat gigi tiruan.

\section{Biaya}

Berdasarkan hasil penelitian yang dilakukan pada masyarakat di desa Treman kecamatan Kauditan tentang persepsi responden terhadap biaya, didapatkan penilaian skor rata-rata sebesar 379. Penilaian tersebut termasuk dalam kategori baik, dimana alternatif jawaban setuju sampai amat sangat setuju.

Penelitian yang dilakukan oleh Sarnizia pada tahun 2008 di Medan menemukan bahwa sebanyak $92,5 \%$ menyatakan biaya yang relatif lebih murah pada tukang gigi menjadi alasan utama dalam memanfaatkan jasa tukang gigi dibandingkan dengan pelayanan kesehatan gigi lainnya dan mengenai biaya pasang gigi palsu yang berlaku menurut tukang gigi umumnya berkisar Rp. 80.000,- sampai Rp. 100.000,tergantung gigi tiruan yang akan dibuatkan bahkan khusus untuk pembuatan gigi tiruan bisa dilakukan cicilan 3 kali sedangkan pada dokter gigi harga yang ditawarkan jauh lebih mahal sesuai dengan kondisi gigi yang akan dibuatkan gigi tiruan dan pasien tidak dapat mencicil. ${ }^{15}$ Hasil penelitian tersebut tentu tidak berbeda jauh dengan penelitian yang penulis lakukan di desa Treman tentang pembuatan gigi tiruan oleh tukang gigi lebih murah dibandingkan dokter gigi bahwa responden merasa pembuatan gigi tiruan oleh tukang gigi lebih murah bahkan dapat dicicil sehingga mereka lebih memilih ke tukang gigi untuk melakukan pembuatan gigi tiruan dibandingkan ke dokter gigi karena alasan ekonomi.

\section{Waktu}

Berdasarkan hasil penelitian yang dilakukan pada masyarakat di desa Treman kecamatan Kauditan tentang persepsi responden terhadap kebutuhan, didapatkan penilaian skor rata-rata sebesar 398. Penilaian tersebut termasuk dalam kategori baik, dimana alternatif jawaban setuju sampai amat sangat setuju mengenai

Penelitian yang dilakukan di desa Treman tersebut menurut responden bahwa tukang gigi bekerja lebih cepat bahkan tukang gigi dapat dipanggil ke rumah-rumah warga untuk dibuatkan gigi tiruan tanpa perlu menunggu lama. Penelitian yang sama juga diperoleh pada penelitian yang dilakukan oleh Teguh pada tahun 2011 di Pulau Kodingareng Makassar menemukan bahwa tukang gigi bekerja secara cepat sehingga pasien tidak menunggu terlalu lama karena rata-rata pasien yang berkunjung di tukang gigi ingin membuat gigi tiruan dan pasien hanya dicetak dan dipasangkan gigi tiruan tanpa memeriksakan kondisi rongga mulut, sehingga akibat yang terjadi biasanya terdapat sisa akar dibawah gigi tiruan yang mengakibatkan peradangan jaringan gingival sedangkan pada dokter gigi pembuatan gigi tiruan lebih lama proses pembuatannya karena membutuhkan proses yang diawali dengan diagnosis, pencetakan rahang, perawatan persiapan, proses laboratorium, dan pemasangan gigi tiruan. ${ }^{16,17}$

\section{Akses}

Penelitian yang dilakukan pada masyarakat di desa Treman kecamatan Kauditan tentang persepsi responden terhadap kebutuhan, didapatkan penilaian skor rata-rata sebesar 395 . Penilaian tersebut termasuk dalam kategori baik, dimana alternatif jawaban setuju sampai amat sangat setuju mengenai

Hasil penelitian di desa Treman menunjukkan bahwa responden melakukan pembuatan gigi tiruan pada tukang gigi. Tukang gigi menjadi pilihan utama masyarakat di desa Treman sebagai pemberi pelayanan gigi karena tukang gigi tersebut memang tinggal dan bermukim di desa Treman tersebut. Selain itu, tidak terdapatnya dokter gigi yang melayani masyarakat di desa Treman serta puskesmas terdekat tidak melayani pembuatan gigi tiruan sehingga masyarakat lebih memilih pergi ke tukang gigi disebabkan jarak dan kepraktisan tempat praktek tukang gigi.

\section{SIMPULAN}

Berdasarkan hasil penelitian mengenai persepsi masyarakat terhadap pemakaian gigi tiruan di desa Treman kecamatan Kauditan, maka disimpulkan yaitu sebagai berikut :

1. Persepsi masyarakat tentang kebutuhan memperoleh skor 366,6 dikategorikan baik.

2. Persepsi masyarakat tentang kompetensi memperoleh skor 236,25 dikategorikan cukup.

3. Persepsi masyarakat tentang biaya memperoleh skor 379 dikategorikan baik.

4. Persepsi masyarakat tentang waktu memperoleh skor 398 dikategorikan baik.

5. Persepsi masyarakat tentang akses memperoleh skor 395dikategorikan baik.

\section{SARAN}

Berdasarkan kesimpulan yang telah dipaparkan, maka saran dalam penelitian ini yaitu sebagai berikut :

1. Bagi Masyarakat

Setelah mengetahui resiko pembuatan gigi tiruan pada tukang gigi maka diharapkan 
penelitian ini dapat menimbulkan kesadaran bagi masyarakat untuk membuat gigi tiruan pada dokter gigi.

2. Bagi Tenaga Kesehatan dan Pemerintah Diharapkan agar pemerintah bersama tenaga kesehatan yang ada dapat mengadakan penyuluhan pada masyarakat tentang resiko penggunaan gigi tiruan pada tukang gigi serta dapat mengupayakan untuk memberikan pelayanan kesehatan gigi dan mulut yang lebih terjangkau kepada masyarakat.

3. Bagi institusi pendidikan dan peneliti

Dapat dilakukan penelitian lebih lanjut dengan sampel yang lebih banyak dan metode yang berbeda, agar wawasan kita tentang persepsi masyarakat terhadap pembuatan gigi tiruan oleh tukang gigi lebih luas.

\section{DAFTAR PUSTAKA}

1. Syamsudin E. Vestibuloplasti sebagian persiapan pembuatan gigi tiruan lepasan. pertemuan ilmiah ilmu kedokteran gigi 2007;212.

2. Jubhari EH. Upaya untuk mengurangi preparasi gigi : Fung shell bridge. Dentofasial J 2007 April;6(1):27.

3. McMillan AS. Emotional effects of tooth loss in community-dwelling elderly people in Hongkong. [serial online]. 2004 [cited 2013 Mei 29]; Available from: http://www.researchgate.net/publication/8585 278Emotional_effects_of_tooth_loss_in_com munitydwelling elderly people in Hong Ko ng/file/79e41509c53d66ec6d.pdf

4. World health organization. Oral health. [serial online] 2012 [cited 2013 April 22]; Available from: URL:http://www.who.int/mediacentre /factsheets/fs318/en/index.html

5. Depertemen Kesehatan Republik Indonesia. Laporan Riset Kesehatan Dasar Nasional 2007. Jakarta: Badan Penelitian dan Pengembangan Kesehatan; 2008.

6. Jubhari EH. Alasan mahasiswa fakultas kedokteran gigi tidak menggunakan gigi tiruan. Dentofasial J 2008 Okt;7(2):125.

7. Kusumawardani E. Buruknya kesehatan gigi dan mulut. Yogyakarta: Siklus; 2011. Hal. 64.

8. Sari K. Fenomena dokter gigi jalanan. Cobra \& Campus 2013 Februari;6:31.

9. Hidayati S, Chusnah A, Mu'afiro A, Suwito J. Tingkat keparahan gingivitis pengguna gigi palsu yang dibuat di tukang gigi pada penduduk RT.5 dan 6 Desa Tambang Ulang Kabupaten Tanah Laut. Buletin Penelitian RSUD Dr.Soetomo J 2009 Desember;11(4):178.
10. Rahina Y, Lily Y, Surtiningsih. Analisis persepsi pasien terhadap pelayanan di RSGM terpadu FKG UNMAS Denpasar. Interdental Jurnal Kedokteran Gigi 2007;5(1):44.

11. Shigli K, Hebbal M, Angadi GS. Attitudes towards replacement of teeth among patients at the Institute of Dental Sciences, Belgaum, India. J Dent Education 2007;71(11):1467-75.

12. Davis DM, Fiske J, Scott B, Radford DR. The emotional effects of tooth loss: a preliminary quantitative study. Br Dent J 2000; 188:503

13. Forgie AH, Scott BJJ, Davis DD. A study to compare the oral health impact profile and satisfaction before and after having replacement complete dentures in England and Scotland. Gerodontology 2005; 22:13742.

14. Peraturan Menteri Kesehatan Nomor 512/MENKES/Per/IV/2007. Izin praktek dan pelaksanaan praktek kedokteran. Jakarta.

15. Meutuah S. Hubungan karakteristik pengguna gigi palsu dengan pemanfaatan jasa tukang gigi di kota medan tahun 2008. Usu repository [serial online] 2008 [cited 2013 juli 13]. Available from: http:// repository.usu.ac.id/bitstream/123456789/147 34/1/09E00980.pdf

16. Putra T. Tingkat kepuasan masyarakat pulau Kodingareng terhadap pelayanan kesehatan gigi dan mulut. Unhas repository [serial online] 2012 [cited 2013 juli 13]. Available from:http://repository.unhas.ac.id/handle/1234 56789/1039

17. Haryanto AG, Margo A, Burhan LK, Suryatenggara F, Setiabudi I. Buku ajar gigi geligi tiruan sebagian lepasan jilid 1. Jakarta: Hipokrates; 2012. Hal.17 